\title{
Performance and emission characteristics of compression ignition engine using methyl ester blends of jatropha and fish oil
}

\author{
K. Bhaskar ${ }^{1}$, S. Sendilvelan ${ }^{2 *}$, V. Muthu ${ }^{3}$ and S. Aravindraj ${ }^{4}$ \\ ${ }^{1,3}$ Department Automobile Engineering, Rajalakshmi Engineering College, Thandalam, \\ Chennai- 602 105, India. Email: kbhaskar66@yahoo.co.in \\ ${ }^{2}$ Department of Mechanical Engineering, Dr. M.G.R Educational and Research Institute, \\ Chennai-600 095, India, *Email: sendilvelan.mech@drmgrdu.ac.in \\ ${ }^{4}$ Automotive Engineering, PSG College of Technology, Coimbatore, Tamil Nadu, \\ Email: aravindrajsethu@gmail.com
}

\begin{abstract}
In this work, biodiesel obtained from the transesterfication of Jatropha seeds and Fish wastes is used as an alternative fuel to diesel in stationary single cylinder diesel engines. The biodiesel obtained has good ignition ability due to its relatively high cetane number compared to that of conventional diesel fuel. The performance, combustion and emission tests using Jatropha Oil Methyl Ester (JOME), Fish Oil Methyl Ester (FOME) and their blends (20\% JOME and 20\% FOME) with diesel were carried out at constant speed and variable loads condition. The results showed that both blends could be used as fuels for diesel engine without any major modification on the engine. Carbon monoxide (CO), UBHC and smoke emissions were observed to be lesser at all loads for both the blends compared to diesel fuel, while NOx emission was slightly higher. JOME blend was found to be better than FOME blend.
\end{abstract}

Keywords: Diesel Engine Performance; Exhaust Emissions; FOME; Fuel Properties; JOME.

\section{INTRODUCTION}

Energy crisis has aggravated the world due to the rapid depletion of fossil fuels and environmental degradation [1]. Due to the reduction in the world's petroleum reserves and growing environmental concerns, there is an extensive demand for non-conventional sources of energy [2]. Augmented regulations on particulate matter and NOx, and also issues raised on greenhouse gas emission like $\mathrm{CO}_{2}$ are the reasons for demanding research work on bio-fuels all over the world [3-6]. Biodiesel derived from the trans-esterification of fats and oils [7-11] is a possible fuel for diesel engines. The properties of this fuel is comparable to that of diesel and can be used directly to run existing diesel engines or as a blend with crude oil diesel [12]. Biodiesel is renewable, biodegradable and non-toxic. With diesel, it increases fuel lubricity and operates in compression ignition engines with little or no modification [13]. Furthermore, biodiesel offers compensations regarding engine wear, cost and availability [14, 15]. Pollutants produced are less harmful comparatively $[16,17]$. Biodiesel has low sulphur content, low aromatic content and oxygen containing compounds due to which the emissions of $\mathrm{SO}_{2}, \mathrm{CO}_{2}, \mathrm{HC}$ and $\mathrm{PM}$ are reduced. Besides, it has good ignition ability in engine owing to its high cetane number compared to that of conventional diesel fuel [10, 18-23]. 
The trans-esterification process is based on the chemical reaction between a triglyceride with an alcohol in the presence of a catalyst, potassium hydroxide, to produce biodiesel and glycerin. Castor, palm, sunflower, peanut and soybean oils can be used as biodiesel sources [24], but all of these are used for cooking purposes. Hence, instead of using edible oils for the production of biodiesel, non-edible oils can be used for the same. Low cost $[25,26]$ renewable raw material is a very important requirement for economical production of biodiesel. Biodiesel produced from waste fish oil is a very good and low cost alternative to petroleum diesel [27]. The fish processing industry generates large quantities of tissue waste and byproducts which are either discarded or retailed at low values for fertilizer or animal feeds [28]. A better way to utilize these byproducts is to convert them into biodiesels for use in diesel engines [29]. India has one of the longest coastal areas in Asia and has excellent potential for fish and fish products including Fish meal and Fish oil [30]. Locally produced fish oil biodiesel blend fuels have the potential to create sustainable energy supply for use in remote regions, together with dramatic cost savings and reduced dependence on imported petroleum products [31]. Easy-tomanufacture [32], cleaner-burning fish oil biodiesel and its blends could potentially replace or reduce traditional diesel fuel requirements in India. This paper presents the experimental results of using 20\% JOME and 20\% FOME blend on the performance and emission characteristics of the engine. This work brings out the possibility to partially replace diesel to reduce dependence on petroleum-based diesel fuel. The use of animal fat to produce biodiesel has attracted public interest recently. The search for aquatic sources for energy production makes economic sense as well as ecological sense [33]. Also, the fish oil obtained has long carbon chain fatty acids which makes combustion to be efficient and reduces carbonaceous emissions greatly [34]. In addition to the purified fish oil obtained from the wastes in the fishing industry, caustic soda is added. Eventually methanol is produced. One $\mathrm{kg}$ of fish oil waste can produce up to $1.13 \mathrm{lts}$ of bio-diesel [35]. Glycerine is a valuable byproduct obtained, which is used for pharmaceutical and cosmetic purposes [36]. In Alaska, roughly 8 million gallons of fish oil is produced each year. Most of the oil is used as boiler fuel for drying the fish meal, while smaller quantities are blended with diesel and used for power production [37]. In 2005, the Food and Agricultural Organization (FAO) estimated the world fish production at 142 million tons, of which $25 \%$ is destined for producing fish meal and oil [38]. In 2008, the amount of wastes was around $50 \%$ of the total fish production and the oil produced ranged from 40$65 \%$ [39]. Based on the above literature survey, the use of J20 and F20 blends with diesel was investigated in this work. The experimental results showed that the above blend can be used as a partial replacement for diesel to reduce dependence on petroleum-based diesel fuel.

\section{EXPERIMENTAL SETUP}

The tests were conducted on a single cylinder, four stroke, naturally aspirated, air-cooled diesel engine coupled with an electrical swinging field dynamometer. The detailed technical specifications of the engine are given in Table 1. Figures 1-2 show a photographic view and the schematic diagram of the experimental set-up. AVL 415 Variable Sampling Smoke meter was used to measure the particulate matter in the exhaust. MRU delta 1600 L Exhaust Gas Analyzer was used to measure HC, CO and NOx emissions. The AVL 615 Indimeter system was used to get the pressure crank angle diagram at various loads using a piezoelectric pressure transducer and an angle encoder and to process the same for getting various parameters such as heat release rate curve, 
peak pressure, angle of occurrence of peak pressure, imep, etc. Fuel consumption was calculated at any load from the measurement of time for 10cc of consumption. Exhaust gas temperature was measured using K-type thermocouple. All equipment were calibrated per the supplier's specifications before beginning the experiments.

Table 1. Test engine specifications

\begin{tabular}{ll}
\hline Specificaions & Description \\
\hline Engine Type & $\begin{array}{l}\text { Four stroke, Air cooled, stationary, constant } \\
\text { speed, direct injection, CI engine }\end{array}$ \\
No. of cylinders & 1 \\
Maximum power & $4.4 \mathrm{~kW}$ at $1500 \mathrm{rpm}$ \\
Maximum torque & $28 \mathrm{~N}-\mathrm{m}$ at $1500 \mathrm{rpm}$ \\
Bore & $87.5 \mathrm{~mm}$ \\
Stroke & $110 \mathrm{~mm}$ \\
Displacement & $661.5 \mathrm{cc}$ \\
Compression Ratio & $17.5: 1$ \\
Injection Timing & $23.4^{0} \mathrm{bTDC}$ \\
Loading type & Swinging field dynamometer \\
\hline
\end{tabular}

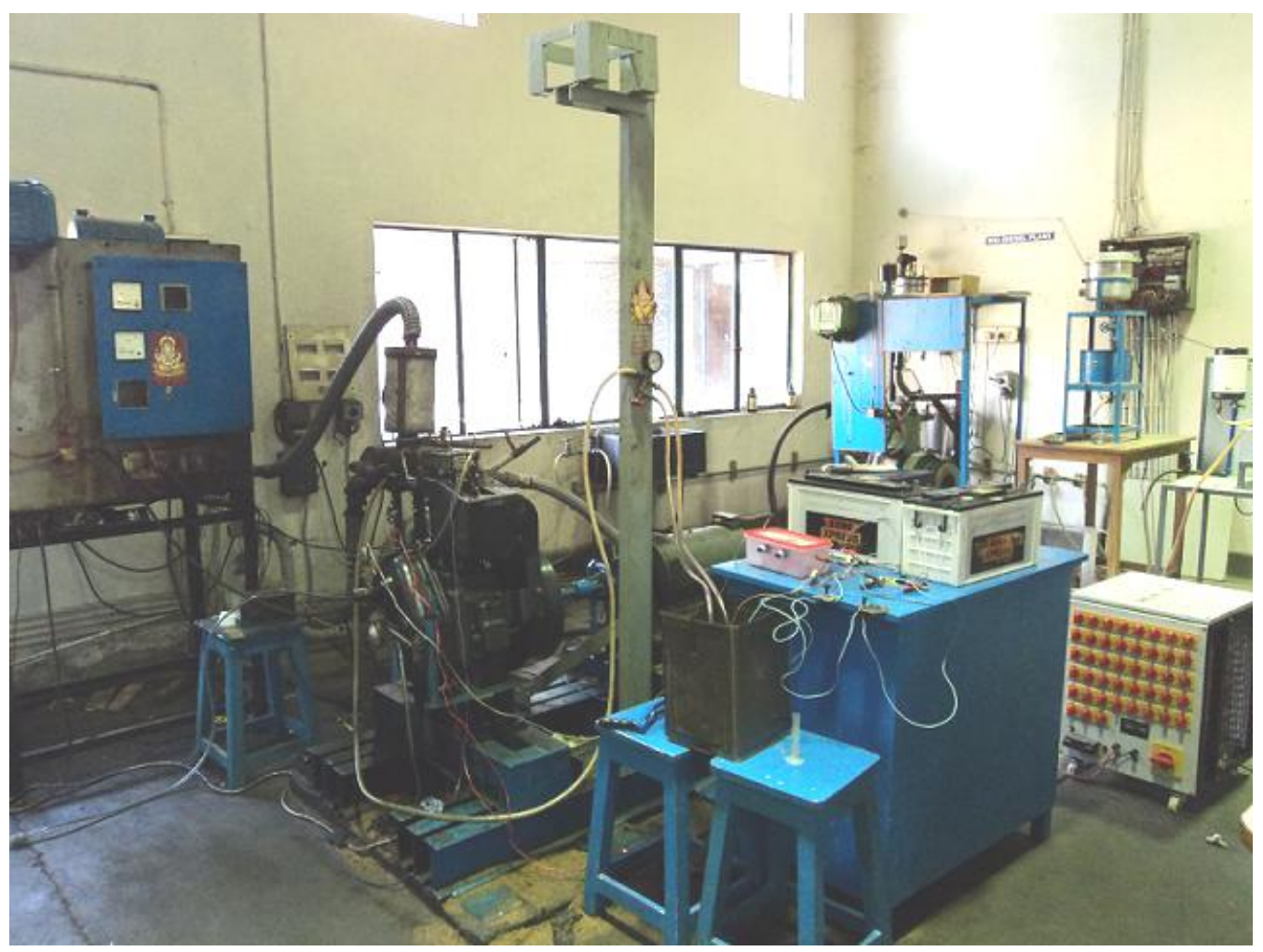

Figure 1. Photographic view of the experimental setup.

\section{Experimental Procedure}

The engine was started with diesel and allowed to warm up until steady state condition was achieved. Engine Speed, fuel consumption rate, exhaust emissions ( $\mathrm{HC}, \mathrm{CO}$, and 
NOx), smoke intensity, pressure-crank angle diagram and exhaust gas temperature were measured at various loads. The experiment was repeated with blends of Jatropha and Fish oil at no load, $25 \%, 50 \%, 75 \%$ and $100 \%$ of the rated power output at a constant speed of $1500 \mathrm{rpm}$.

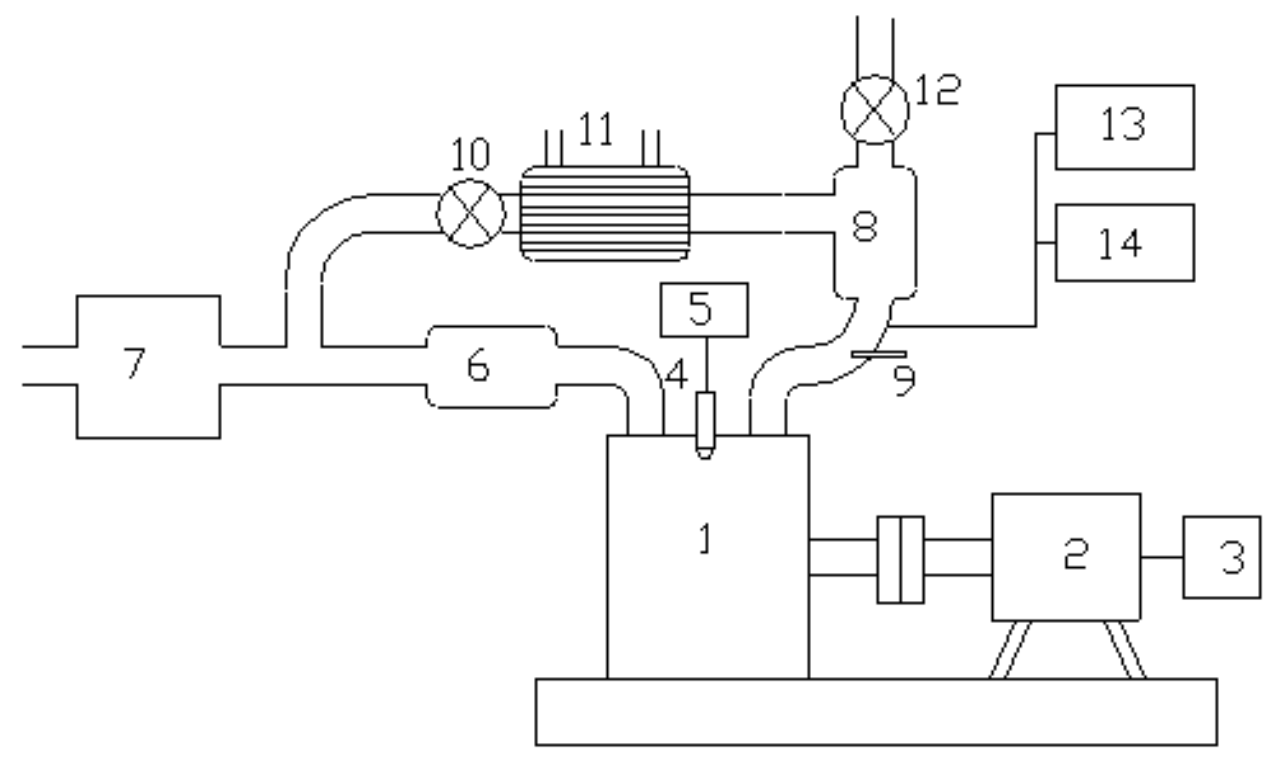

$\begin{array}{llcl}1 & \text { Diesel Engine } & 8 & \text { Settling chamber } \\ 2 & \text { Electrical Dynamometer } & 9 & \text { Thermocouple } \\ 3 & \text { Dynamometer Controls } & 10 & \text { EGR Valve } \\ 4 & \text { Main Injector } & 11 & \text { EGR Cooler } \\ 5 & \text { Fuel flow measurement } & 12 & \text { Back pressure control valve } \\ 6 & \text { Mixing chamber } & 13 & \text { Exhaust gas analyzer } \\ 7 & \text { Air flow measurement } & 14 & \text { AVL smoke meter }\end{array}$

Figure 2. Schematic diagram of the experimental setup.

\section{Error Analysis}

Errors and uncertainties in the experiment are important to determine the accuracy of the results. So, instruments were carefully selected and the uncertainty percentages of various parameters are given in Table 2.

\section{RESULTS AND DISCUSSION}

\section{Brake Thermal Efficiency}

Figure 3 shows the variation of brake thermal efficiency with brake power, which was found to increase with increasing brake power as observed by investigators [27, 28, 30]. The brake thermal efficiency for 20\% JOME and 20\% FOME blends were slightly lower than that of diesel at all loads. At any load, the energy input given by (mass flow rate of fuel $x$ calorific value) was higher for biodiesel blends compared to diesel. Hence the brake thermal efficiency was lower for biodiesel. The engine was operated under constant injection timing. As methyl esters and their blends had smaller ignition delay, combustion was initiated well before TDC was reached. This increased the compression work and reduced the brake thermal efficiency of the engine [40]. The start of heat release occured 
well before TDC for methyl esters and their blends [41], which causes appreciable deviation from the ideal cycle, hence lower thermal efficiency. Blends of both methyl esters showed the same trend, but with a difference that the brake thermal efficiency was slightly higher for blends of JOME due to higher oxygen content, and hence better combustion.

Table 2. List of instruments and their range, accuracy, and uncertainty.

\begin{tabular}{|c|c|c|c|c|}
\hline $\begin{array}{l}\text { Sl. } \\
\text { No. }\end{array}$ & Instruments & Range & Accuracy & $\begin{array}{l}\text { Percentage } \\
\text { of } \\
\text { uncertainty }\end{array}$ \\
\hline \multirow{4}{*}{1} & Gas analyzer & & & \\
\hline & $\mathrm{CO}$ & $0-15.00 \%$ & $\pm 0.06 \%$ & $\pm 5 \%$ \\
\hline & Hydro carbon (HC) & $\begin{array}{l}0-20000 \mathrm{ppm} \\
\text { n-hexane }\end{array}$ & $\pm 0.12 \mathrm{ppm}$ & $\pm 5 \%$ \\
\hline & NOx & $0-2000 \mathrm{ppm}$ & $\pm 5 \mathrm{ppm}$ & $\pm 5 \%$ \\
\hline 2 & Smoke meter & $0-32000 \mathrm{mg} / \mathrm{m}^{3}$ & $\pm 0.01 \mathrm{mg} / \mathrm{m}^{3}$ & $\pm 5 \%$ \\
\hline 3 & $\begin{array}{l}\text { K type Thermocouple } \\
\text { used for Exhaust Gas } \\
\text { Temperature } \\
\text { measurement }\end{array}$ & $0-1000$ & $\pm^{\circ} 1$ & \pm 0.15 \\
\hline 4 & Speed measuring unit & 0-9,999 rpm & $5 \pm 10 \mathrm{rpm}$ & \pm 0.1 \\
\hline 5 & Pressure pickup & $0-250$ bar & \pm 0.1 & \pm 0.1 \\
\hline 6 & Crank Angle encoder & $0-360^{\circ}$ & $\pm 1^{\circ}$ & \pm 0.2 \\
\hline
\end{tabular}

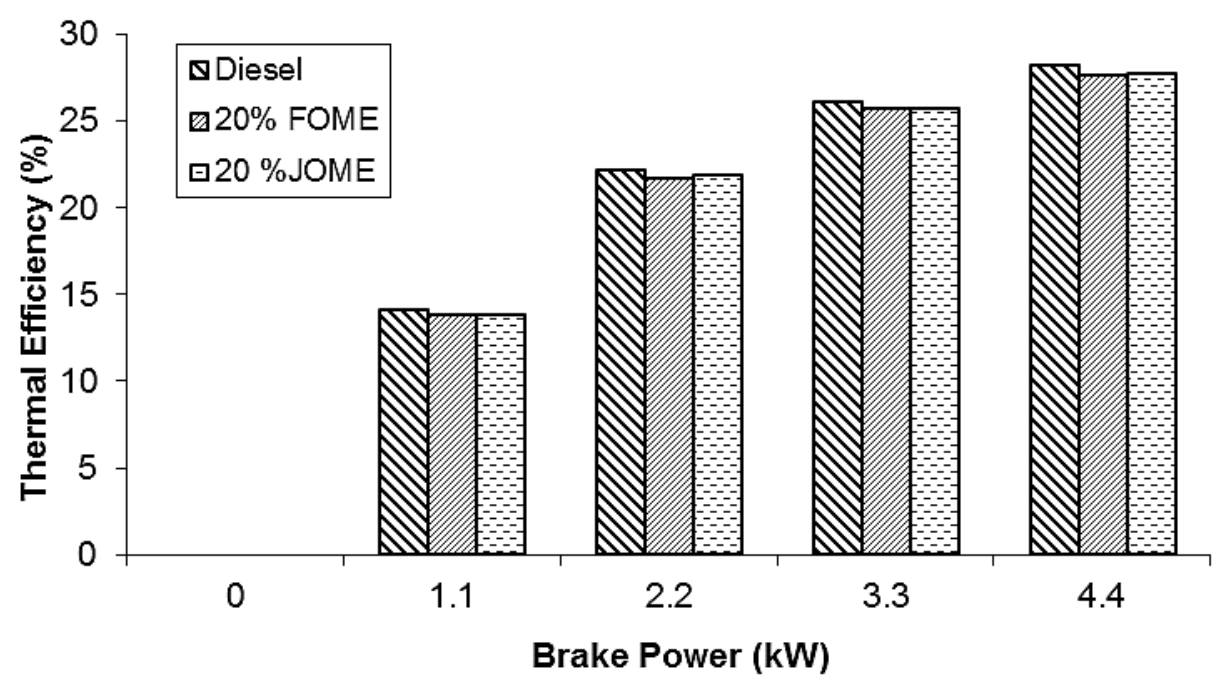

Figure 3. Variation of brake power against thermal efficiency.

\section{Brake Specific Energy Consumption}

Figure 4 shows the variation of brake specific energy consumption with brake power. BSEC is the input energy required to develop a unit power output and by comparing methyl esters with diesel, methyl esters showed comparatively higher value of BSEC. The slight increase was due to lower calorific value of the esters compared to diesel [42]. When comparisons were made between 20\% FOME and 20\% JOME, 20\% FOME showed slightly higher value, which is attributed to higher density of FOME (Table 3). 


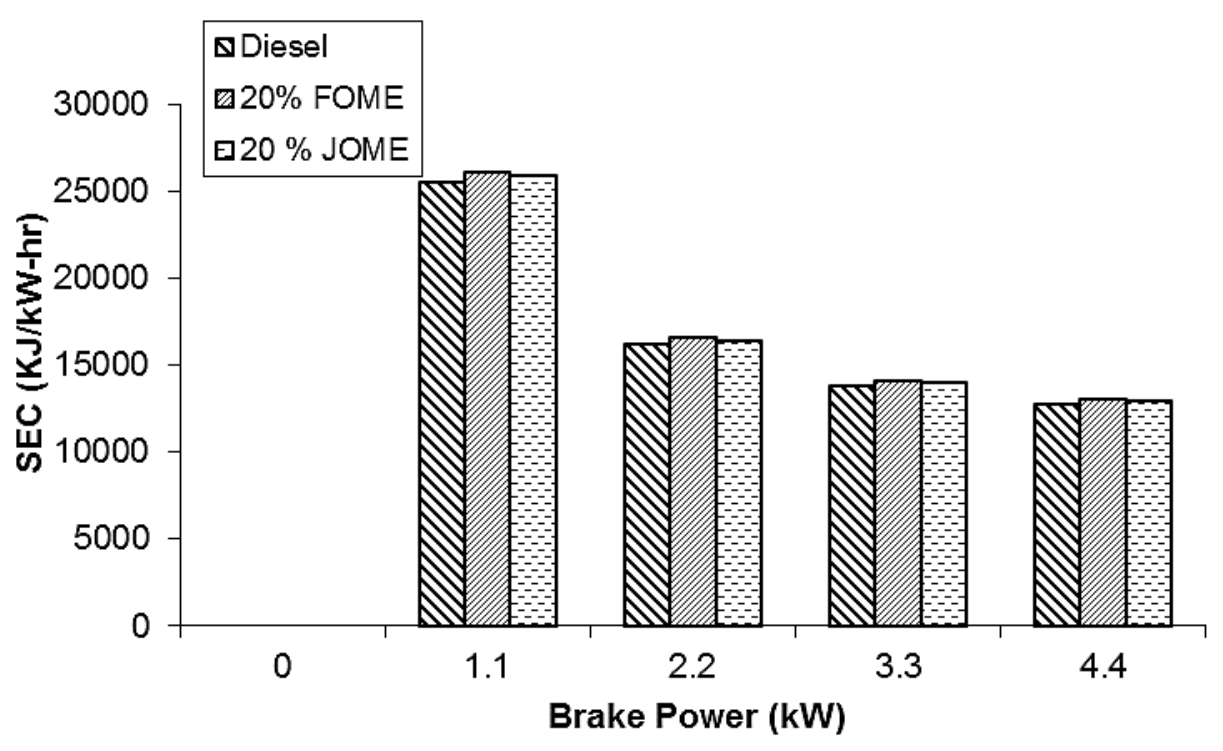

Figure 4. Brake power versus SEC.

Table 3. Comparison between the fatty acid composition (wt \%) of fish oil methyl esters and jatropha oil methyl esters (as provided by the suppliers).

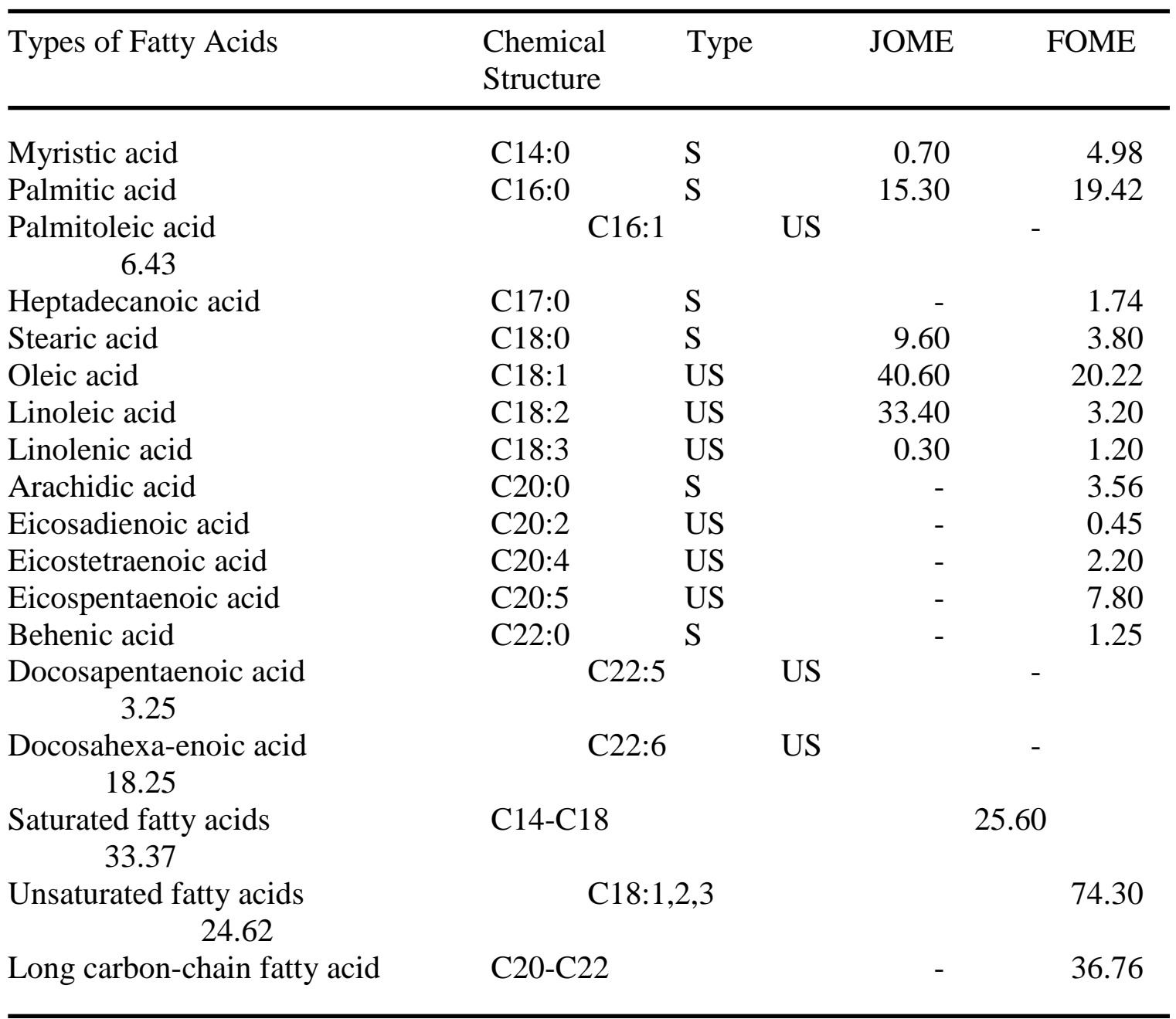




\section{Exhaust Gas Temperature}

The exhaust gas leaving the cylinder determines the extent of temperature reached during the combustion process [43]. With increasing load, the temperature of the exhaust gases increased for all of the fuels. It was also observed that the exhaust gas temperature increased with percentage of methyl ester in the fuel for all of the loads (Figure 5). This may be due to the oxygen content in methyl esters, which improved combustion [44]. Also, poor fuel atomization and vaporization due to higher viscosity of methyl esters and their blends resulted in late burning of the injected fuel and higher exhaust gas temperature [45].

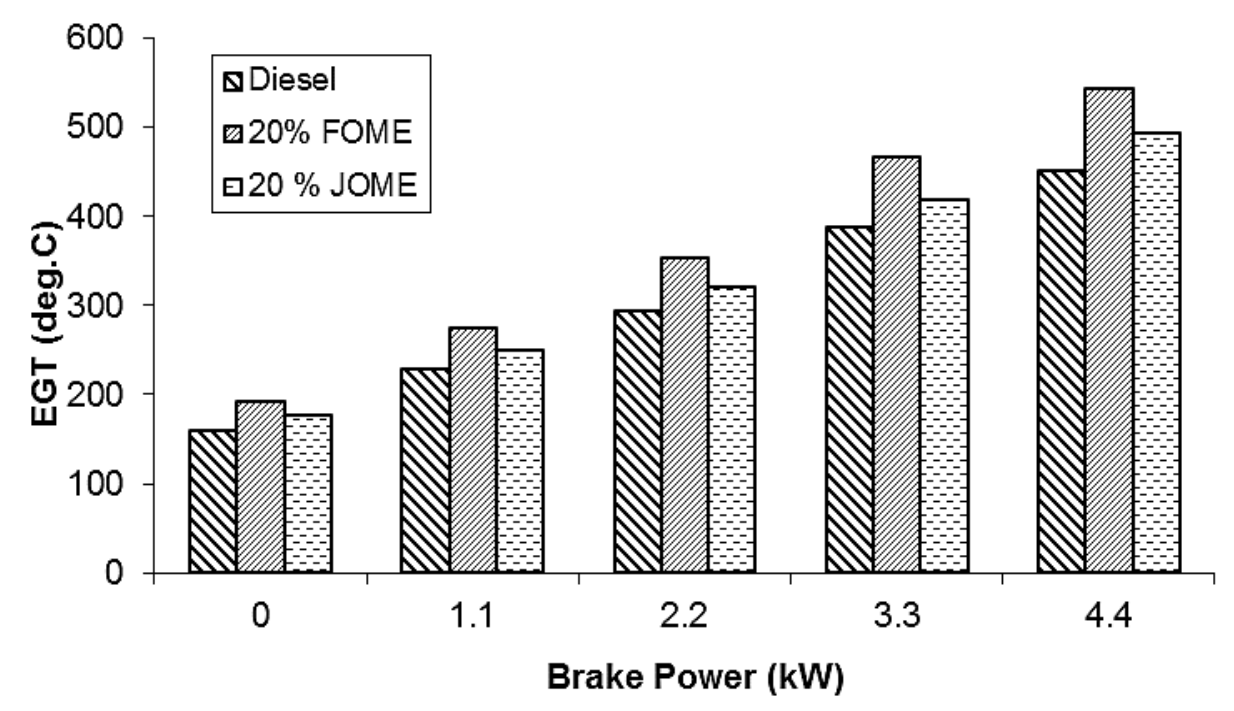

Figure 5. Brake power versus EGT.

Table 4. Fuel Properties of Biodiesel from FOME, JOME and Diesel fuel (Measured).

\begin{tabular}{lccccc}
\hline \multicolumn{1}{c}{ Fuel Property } & Units & Diesel & $\begin{array}{l}\text { Limits as per } \\
\text { IS 15607-2005 } \\
\text { ASTM D6751 }\end{array}$ & JOME & FOME \\
& & & $860-900$ & 882 & 890 \\
\hline $\begin{array}{l}\text { Density at } 15^{\circ} \mathrm{C} \\
\text { Kinematic Viscosity at } 40\end{array}$ & $\mathrm{~kg} / \mathrm{m}^{3}$ & 830 & $1.9-6.0$ & 4.5 & 5.2 \\
${ }^{\circ} \mathrm{C}$ & & 3.52 & 120 & 160 & 157 \\
Flash Point & ${ }^{\circ} \mathrm{C}$ & 54 & - & 54 & 52.4 \\
Calculated Cetane Index & - & 50 & - & 39.64 & 40.54 \\
Higher Heating Value & $\mathrm{MJ} / \mathrm{kg}$ & - & - & 10.8 & 8.1 \\
$\begin{array}{l}\text { Element O } \\
\text { (Given by Supplier) }\end{array}$ & $\mathrm{wt} \%$ & - & 0.5 max & 0.14 & 1.32 \\
\multicolumn{1}{c}{ Acid Number } & $\mathrm{mg}$ & 0.2 & & & \\
\hline \multicolumn{1}{c}{$\mathrm{KOH} / \mathrm{g}$} & & & & &
\end{tabular}

\section{Hydrocarbon Emissions}

Figure 6 shows the variation of $\mathrm{HC}$ emission with brake power. It can be seen that with increasing brake power, $\mathrm{HC}$ emission increased for all test fuels, and there was reduction in $\mathrm{HC}$ emission for 20\% JOME and 20\% FOME blends compared to diesel due to the presence of oxygen content in their molecular structure which leads to efficient combustion [46]. With methyl esters having higher Cetane Index (CI) than diesel, the delay period was reduced and led to effective combustion, which reduced $\mathrm{HC}$ emission 
to a greater extent [47]. HC emission for 20\% JOME was lesser than 20\% FOME as the oxygen content by weight for J20 was greater than 20\% FOME (Table 4).

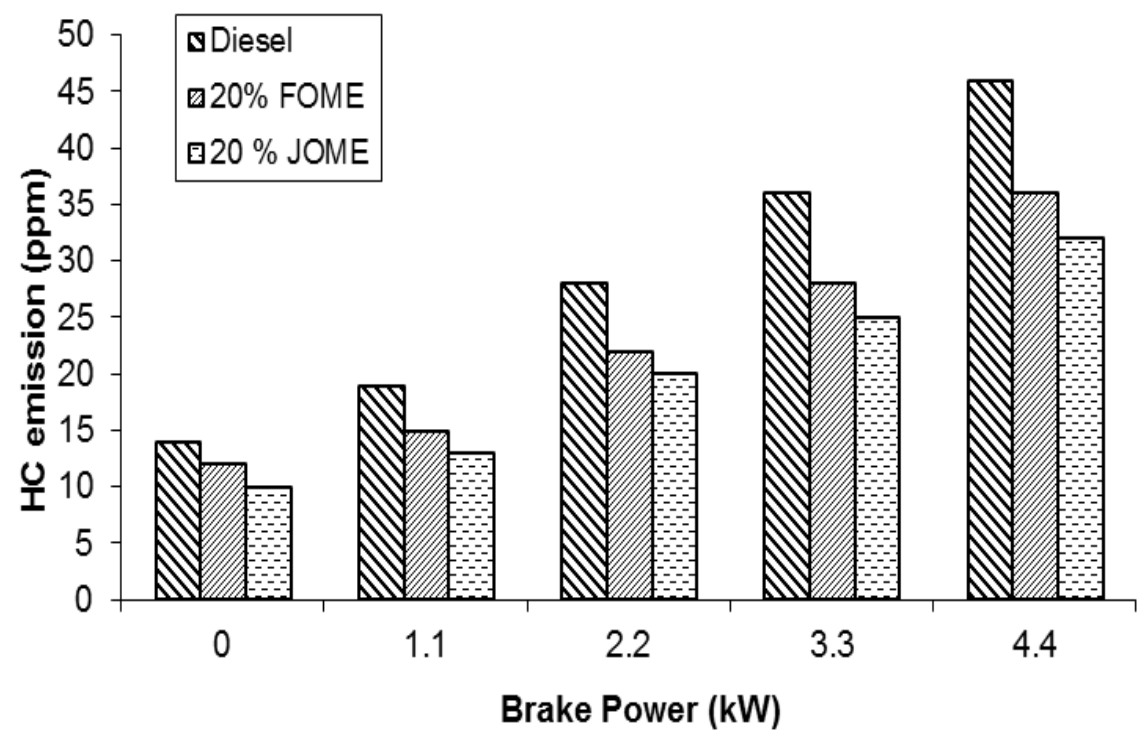

Figure 6. Brake power vrsus $\mathrm{HC}$ emission.

\section{Carbon-Monoxide Emissions}

Figure 7 shows the variation of carbon monoxide emissions with brake power. With increasing brake power, $\mathrm{CO}$ emission increased for all test fuels. $\mathrm{CO}$ emission resulted from the lack of oxygen during combustion. Methyl esters with higher oxygen content produced efficient and effective combustion [48] and higher cetane index [45], leading to lower $\mathrm{CO}$ emission. Lower carbon to hydrogen ratio of methyl esters also results in lower CO emission. By comparing 20\% JOME and 20\% FOME, CO emission was lower for Jatropha blend as $20 \%$ JOME has $10.8 \%$ oxygen content compared to $8.1 \%$ oxygen content of $20 \%$ FOME. Higher cetane index of 20\% JOME compared to 20\% FOME also contributed to lower CO emission.

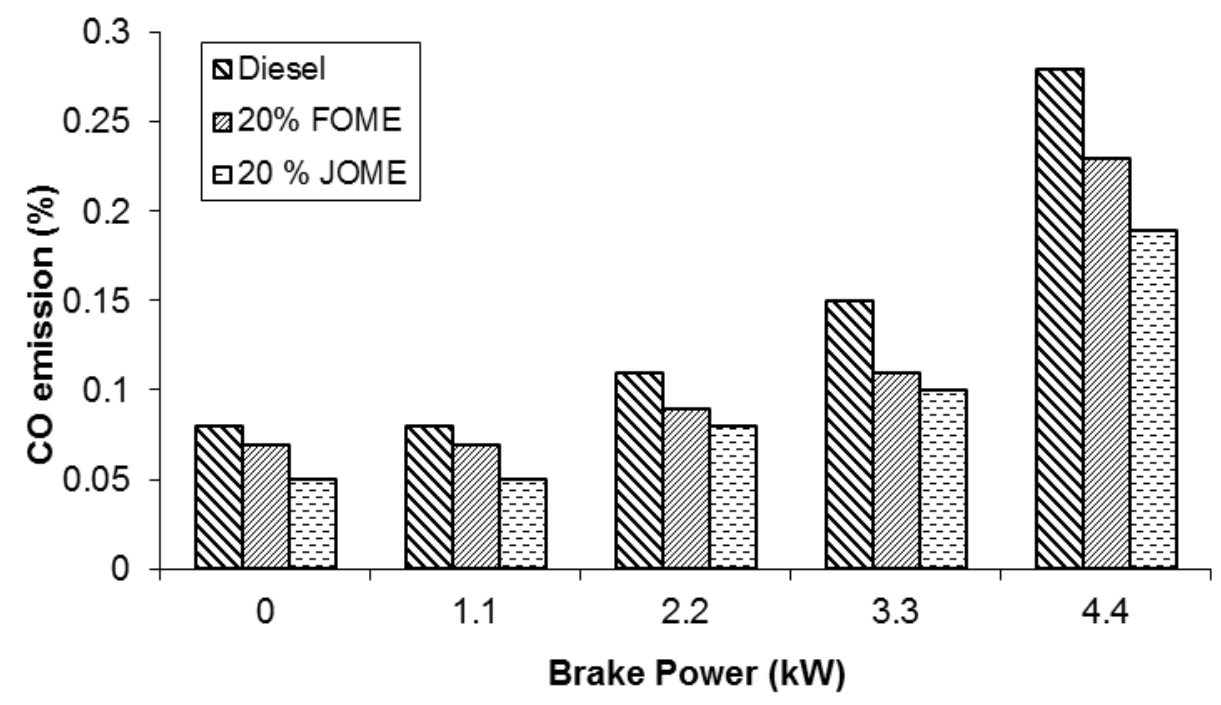

Figure 7. Brake power vs $\mathrm{CO}$ emission 


\section{NOx Emission}

The NOx emission of diesel and the methyl esters are shown in Figure 8. It was found that NOx emission increased with brake power for all of the fuels tested. By comparing J20 and F20 with diesel, methyl esters showed higher value of NOx emission. This is mainly due to higher oxygen content of methyl esters [49]. The oxygen content of diesel, JOME and FOME was $0.3 \%, 10.8 \%$ and $8.1 \%$ respectively. Because of higher oxygen content and increased energy input (mass flow rate of fuel x Calorific Value) combustion was better as observed in higher exhaust temperature [50]. As NOx emission increases with cylinder temperature and oxygen availability, it is higher for the methyl esters [51]. The 20\% FOME showed higher value of NOx compared to $20 \%$ JOME as it contains unsaturated fatty acids including C20:5 and C22:6 and long carbon-chain methyl ester fatty acids in higher proportion than in the Jatropha oil methyl esters. (Table 4)

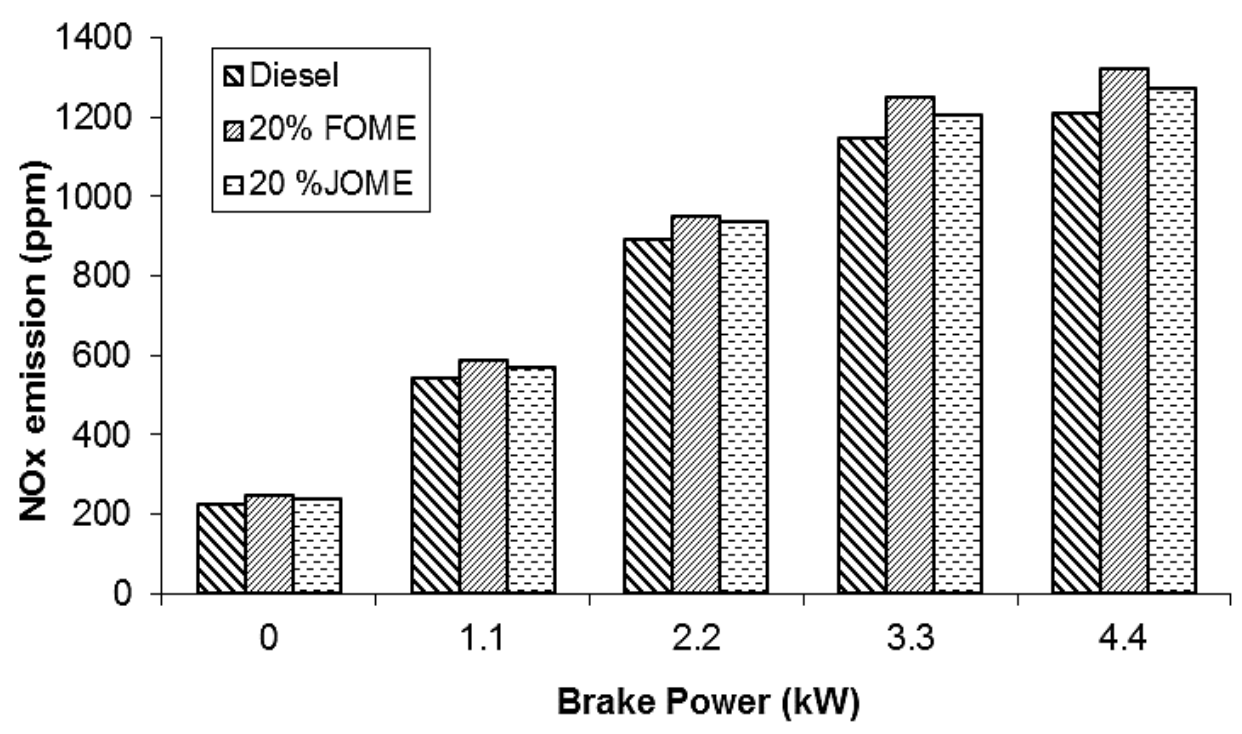

Figure 8. Brake power vs $\mathrm{NO}_{\mathrm{x}}$ emission

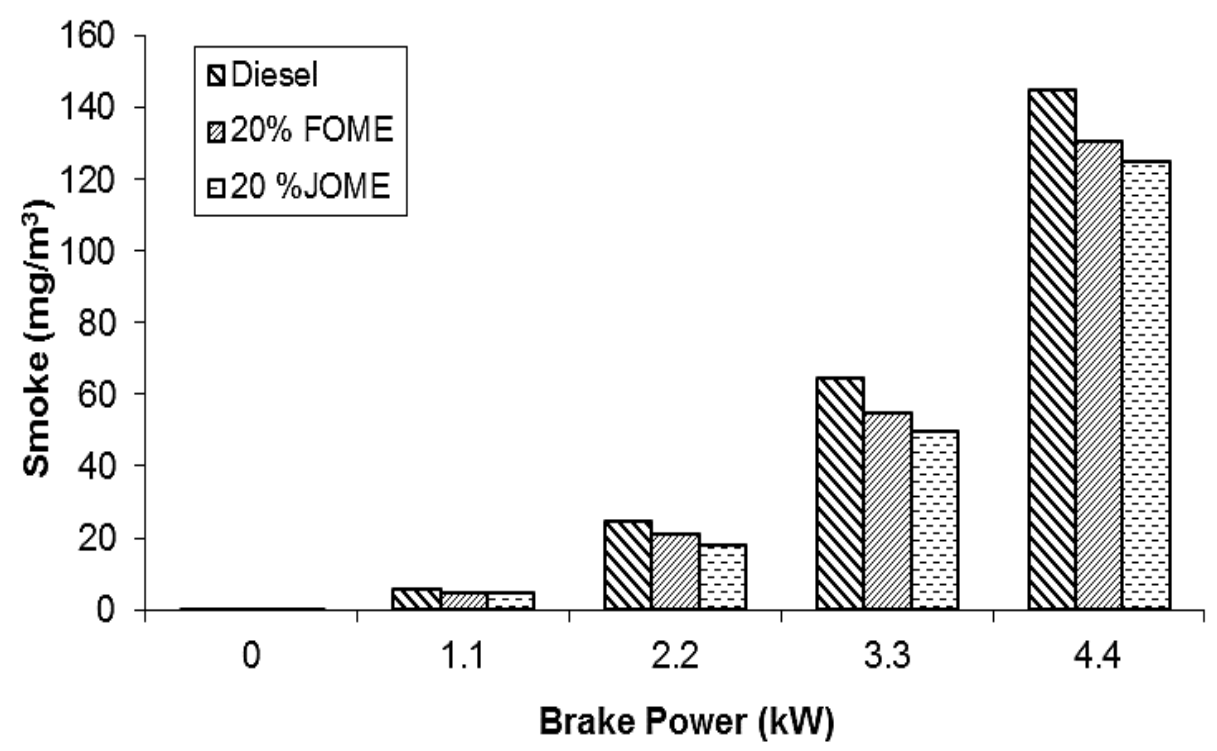

Figure 9. Brake power vs Smoke. 


\section{Smoke Emissions}

Figure 9 shows that smoke emissions increasesd with brake power. It was observed that $20 \%$ JOME and 20\% FOME showed lower value of smoke compared to diesel due to higher oxygen content and higher cetane index, which improved the combustion process [52]. By comparing 20\% FOME and 20\% JOME, 20\% FOME showed higher value of smoke due to higher kinematic viscosity and density, which affects the volatilization and atomization process of the fuel particles [53]. In addition, FOME has long carbon chains fatty acids in the range of $\mathrm{C} 20-\mathrm{C} 22$ which is considered to be larger than those of JOME and hence F20 showed greater value of smoke.

\section{CONCLUSION}

The engine performance and emission characteristics of 20\% JOME and FOME blends were investigated and compared with those of normal diesel fuel. It was seen that the engine can be run without any modification to these fuels. The results of this study are summarized as follows:

1. The brake thermal efficiency of the engine with these fuels was slightly lower than that of diesel. The efficiency of JOME was higher than that of FOME at all loads.

2. $\mathrm{HC}, \mathrm{CO}$ and PM emissions of these fuels were lower compared to those of diesel , and JOME was better than FOME in this regard.

3. Exhaust gas temperature and NOx were higher for these fuels compared to diesel. FOME results in the highest EGT and largest NOx emission at all loads. NOx emission can be reduced by other means such as EGR, retarded injection timing, higher injection pressure.

4. FOME can be produced economically in the coastal regions where discarded fish parts are available cheaply.

Scope for future work:

1. A longer duration of study using these fuels and their effects on carbon deposits on various parts of engine and lubrication oil contamination.

2. The test can be extended to multi cylinder engines which are commonly used in automobiles.

\section{ACKNOWLEDGEMENTS}

The authors would like to be obliged to Dr.M.G.R. Educational and Research Institute, University and Rajalakshmi Engineering College for providing laboratory facilities.

\section{REFERENCES}

[1] Fazal M, Haseeb A, Masjuki H. Biodiesel feasibility study: an evaluation of material compatibility; performance; emission and engine durability. Renewable and Sustainable Energy Reviews. 2011;15:1314-24.

[2] Leung DY, Wu X, Leung M. A review on biodiesel production using catalyzed transesterification. Applied Energy. 2010;87:1083-95.

[3] Nadeem M, Rangkuti C, Anuar K, Haq M, Tan I, Shah S. Diesel engine performance and emission evaluation using emulsified fuels stabilized by conventional and gemini surfactants. Fuel. 2006;85:2111-9. 
[4] Jaichandar S, Annamalai K. Jatropha oil methyl ester as diesel engine fuel - an experimental investigation. International Journal of Automotive and Mechanical Engineering. 2016;13:3248-61.

[5] Hasan MM, Rahman MM. Homogeneous charge compression ignition combustion: Advantages over compression ignition combustion, challenges and solutions. Renewable and Sustainable Energy Reviews. 2016;57:282-91.

[6] Rahman MM, Kamil M, Bakar RA. Engine performance and optimum injection timing for 4-cylinder direct injection hydrogen fueled engine. Simulation Modelling Practice and Theory. 2011;19(2): 734-751.

[7] Ma F, Hanna MA. Biodiesel production: a review. Bioresource Technology. 1999;70:1-15.

[8] Mohanamurugan S, Sendilvelan S. Emission and combustion characteristics of different fuel In A HCCI engine. International Journal of Automotive and Mechanical Engineering. 2011;3:279-92.

[9] Kettner M, Dechent S, Hofmann M, Huber E, Arruga H, Mamat R, et al. Investigating the influence of water injection on the emissions of a diesel engine. Journal of Mechanical Engineering and Sciences. 2016;10:1863-81.

[10] Ghafoori M, Ghobadian B, Najafi G, Layeghi M, Rashidi A, Mamat R. Effect of nano-particles on the performance and emission of a diesel engine using biodieseldiesel blend. International Journal of Automotive and Mechanical Engineering. 2015;12:3097-108.

[11] Babu AR, Amba Prasad Rao G, Hari Prasad T. Direct injection of water mist in an intake manifold spark ignition engine. International Journal of Automotive and Mechanical Engineering. 2015;12:2809-19.

[12] Helwani Z, Othman M, Aziz N, Fernando W, Kim J. Technologies for production of biodiesel focusing on green catalytic techniques: a review. Fuel Processing Technology. 2009;90:1502-14.

[13] Meher L, Sagar DV, Naik S. Technical aspects of biodiesel production by transesterification - a review. Renewable and Sustainable Energy Reviews. 2006;10:248-68.

[14] Dorado M, Ballesteros E, Arnal J, Gomez J, Lopez F. Exhaust emissions from a Diesel engine fueled with transesterified waste olive oil 氺. Fuel. 2003;82:1311-5.

[15] Khan SA, Hussain MZ, Prasad S, Banerjee U. Prospects of biodiesel production from microalgae in India. Renewable and Sustainable Energy Reviews. 2009;13:2361-72.

[16] Lin C-Y, Li R-J. Engine performance and emission characteristics of marine fishoil biodiesel produced from the discarded parts of marine fish. Fuel Processing Technology. 2009;90:883-8.

[17] Sundar Raj C, Sendilvelan S. Effect of oxygenated hydrocarbon additives on exhaust emission of a diesel engine. International Journal of Automotive and Mechanical Engineering. 2010;2:144-56.

[18] Yoon SH, Suh HK, Lee CS. Effect of spray and EGR rate on the combustion and emission characteristics of biodiesel fuel in a compression ignition engine. Energy and Fuels. 2009;23:1486-93.

[19] Park SH, Suh HK, Lee CS. Nozzle flow and atomization characteristics of ethanol blended biodiesel fuel. Renewable energy. 2010;35:144-50.

[20] Hasan MM, Rahman MM, Kadirgama K. A Review on Homogeneous Charge Compression Ignition Engine Performance Using Biodiesel-Diesel Blend as a 

jatropha and fish oil

Fuel. International Journal of Automotive and Mechanical Engineering. 2015;11:2199-211.

[21] Rostami S, Ghobadian B, Kiani Deh Kiani M. Effect of the Injection Timing on the Performance of a Diesel Engine Using Diesel-Biodiesel Blends. International Journal of Automotive and Mechanical Engineering. 2014;10:1945-58.

[22] Hairuddin AA, Wandel AP, Yusaf T. An introduction to a homogeneous charge compression ignition engine. Journal of Mechanical Engineering and Sciences. 2014;7:1042-52.

[23] Rahman MM, Kamil M, Bakar RA. Engine performance and optimum injection timing for 4-cylinder direct injection hydrogen fueled engine. Simulation Modelling Practice and Theory. 2011;19:734-51.

[24] Valente OS, Da Silva MJ, Pasa VMD, Belchior CRP, Sodré JR. Fuel consumption and emissions from a diesel power generator fuelled with castor oil and soybean biodiesel. Fuel. 2010;89:3637-42.

[25] Srivastava A, Prasad R. Triglycerides-based diesel fuels. Renewable and sustainable energy reviews. 2000;4:111-33.

[26] Yusop A, Mamat R, Mat Yasin M, Ali OM. Effects of particulate matter emissions of diesel engine using diesel-methanol blends. Journal of Mechanical Engineering and Sciences. 2014;6:959-67.

[27] Canakci M, Van Gerpen JH. Comparison of engine performance and emissions for petroleum diesel fuel, yellow grease biodiesel, and soybean oil biodiesel. Transactions of the ASAE. 2003;46:937-44.

[28] Yasin MHM, Mamat R, Sharma K, Yusop AF. Influence of palm methyl ester (PME) as an alternative fuel in multicylinder diesel engine. Journal Mechanical Engineering and Sciences. 2012;3:331-9.

[29] Manohar RM, Prabhahar M, Sendilvelan S. Experimental Investigation of Combustion and Emission Characteristics of Engine is Fueled with Diesel and UVOME Blends of B20K and B80K. European Journal of Scientific Research. 2012;76:327-34.

[30] Sarkar U, Pathak A, Lakra W. Conservation of freshwater fish resources of India: new approaches, assessment and challenges. Biodiversity and Conservation. 2008;17:2495-511.

[31] Atabani A, Silitonga A, Ong H, Mahlia T, Masjuki H, Badruddin IA, et al. Nonedible vegetable oils: a critical evaluation of oil extraction, fatty acid compositions, biodiesel production, characteristics, engine performance and emissions production. Renewable and Sustainable Energy Reviews. 2013;18:21145.

[32] Rao GLN, Sampath S, Rajagopal K. Experimental studies on the combustion and emission characteristics of a diesel engine fuelled with used cooking oil methyl ester and its diesel blends. International Journal Engineering and Applied Sciences. 2008;4:64-70.

[33] Bhaskar K, Nagarajan G, Sampath S. Optimization of FOME (fish oil methyl esters) blend and EGR (exhaust gas recirculation) for simultaneous control of NO $\mathrm{x}$ and particulate matter emissions in diesel engines. Energy. 2013;62:224-34.

[34] Wall R, Ross RP, Fitzgerald GF, Stanton C. Fatty acids from fish: the antiinflammatory potential of long-chain omega-3 fatty acids. Nutrition Reviews. 2010;68:280-9. 
[35] Varuvel EG, Mrad N, Tazerout M, Aloui F. Assessment of liquid fuel (bio-oil) production from waste fish fat and utilization in diesel engine. Applied Energy. 2012;100:249-57.

[36] Adeoti IA, Hawboldt K. A review of lipid extraction from fish processing byproduct for use as a biofuel. Biomass and Bioenergy. 2014;63:330-40.

[37] Steigers JA. Demonstrating the use of fish oil as fuel in a large stationary diesel engine. Advances in seafood byproducts conference proceedings, Alaska Sea Grant, Fairbanks, AK2002. p. 187-200.

[38] Trites AW, Christensen V, Pauly D. Competition between fisheries and marine mammals for prey and primary production in the Pacific Ocean. Journal of Northwest Atlantic Fishery Science. 1997;22:173-87.

[39] Wisniewski A, Wiggers V, Simionatto E, Meier H, Barros A, Madureira L. Biofuels from waste fish oil pyrolysis: chemical composition. Fuel. 2010;89:5638.

[40] Hamdan M, Khalil RH. Simulation of compression engine powered by Biofuels. Energy Conversion and Management. 2010;51:1714-8.

[41] Sinha S, Agarwal A. Experimental investigation of the combustion characteristics of a biodiesel (rice-bran oil methyl ester)-fuelled direct-injection transportation diesel engine. Proceedings of the Institution of Mechanical Engineers, Part D: Journal of Automobile Engineering. 2007;221:921-32.

[42] Kalyani Radha K, Naga Sarada S, Rajagopal K, Nagesh EL. Performance and emission characteristics of CI engine operated on vegetable oils as alternate fuels. International Journal of Automotive and Mechanical Engineering. 2011;4:414-27.

[43] Maiboom A, Tauzia X, Hétet J-F. Experimental study of various effects of exhaust gas recirculation (EGR) on combustion and emissions of an automotive direct injection diesel engine. Energy. 2008;33:22-34.

[44] Sukjit E, Herreros J, Dearn K, García-Contreras R, Tsolakis A. The effect of the addition of individual methyl esters on the combustion and emissions of ethanol and butanol-diesel blends. Energy. 2012;42:364-74.

[45] Yoon SH, Lee CS. Experimental investigation on the combustion and exhaust emission characteristics of biogas-biodiesel dual-fuel combustion in a CI engine. Fuel Processing Technology. 2011;92:992-1000.

[46] Shukri M, Rahman M, Ramasamy D, Kadirgama K. Artificial neural network optimization modeling on engine performance of diesel engine using biodiesel fuel. International Journal of Automotive and Mechanical Engineering. 2015;11:2332-47.

[47] Xing-cai L, Jian-Guang Y, Wu-Gao Z, Zhen H. Effect of cetane number improver on heat release rate and emissions of high speed diesel engine fueled with ethanoldiesel blend fuel. Fuel. 2004;83:2013-20.

[48] Knothe G. Dependence of biodiesel fuel properties on the structure of fatty acid alkyl esters. Fuel Processing Technology. 2005;86:1059-70.

[49] Wu F, Wang J, Chen W, Shuai S. A study on emission performance of a diesel engine fueled with five typical methyl ester biodiesels. Atmospheric Environment. 2009;43:1481-5.

[50] Chattopadhyay S, Sen R. Fuel properties, engine performance and environmental benefits of biodiesel produced by a green process. Applied energy. 2013;105:31926. 
[51] Agarwal D, Sinha S, Agarwal AK. Experimental investigation of control of NOx emissions in biodiesel-fueled compression ignition engine. Renewable Energy. 2006;31:2356-69.

[52] Ren Y, Huang Z, Miao H, Di Y, Jiang D, Zeng K, et al. Combustion and emissions of a DI diesel engine fuelled with diesel-oxygenate blends. Fuel. 2008;87:2691-7.

[53] Knothe G, Steidley KR. Kinematic viscosity of biodiesel fuel components and related compounds. Influence of compound structure and comparison to petrodiesel fuel components. Fuel. 2005;84:1059-65. 